\title{
Social Aims of Art Criticism
}

\author{
Dorogova Ludmila \\ Professional Development Academy for the Arts, Culture, and Tourism \\ Moscow, Russia \\ e-mail: L.N.Dorog@mail.ru
}

\begin{abstract}
The article dwells upon the aims of art criticism in the mental life of society.

Keywords-critical evaluation of art pieces; moral and aesthetic criteria of art criticism; review; censorship; selfactualization; mystification; cultivation of aesthetic taste; ranking of artworks
\end{abstract}

\section{INTRODUCTION}

Art criticism is an integral part of the artistic life of society. Since the very beginning, art criticism as a particular kind of mental work has always presupposed the evaluation of a piece of art by the artist himself as well as by those for whom this piece of art was created. A critical judgement about any artwork inevitably implies both aesthetic and moral evaluation which is related to a range of different factors such as professional competence of a critic and his or her experience in a specific art field, which gives the critic the right to pass an aesthetic judgement, the sense of justice, mastery of language, which allows a critic to express his or her opinion in an adequate way without running the risk of offending the artist by a careless statement regulated by taste.

The analysis of a work of art underlies any critical judgement about it and represents, on the one hand, deep knowledge of this particular piece of art and, on the other hand, gives an insight into the critic's personality, reveals his or her aesthetic preferences and art erudition. It refers to professional arts critics and "amateur critics" as well. Nevertheless, the quality of a critical analysis conducted by a representative of each group will differ considerably.

\section{QUINTESSENCE OF ART CRITICISM "ProfESSIONALS" AND "AMATEURS"}

It is a tradition to consider the analysis of an artwork the prerogative of arts critics. There are a great number of experts who basically deal with tracking, studying and describing either once created works of art (art history) or modern artefacts. It is not a coincidence that art criticism is usually defined as a triad including the history of a particular art form, the theory of this art form and the methodology of critical art analysis. The last element is often referred to as reviewing. A review is a critical analysis and evaluation of a work of art or science. A reviewer's task is to evaluate the work of an artist after studying it from different aspects: how does the work of art meet the requirements of a specific genre?; how do the chosen artistic means correspond to the work's idea?; what served as the impulse for creating this work and influenced the choice of subject, artistic means and message?; how far does the author's mastery reach?; what contribution does this work make to the artistic development of society?; what is the moral effect of the work on the audience?; etc.

To accomplish this task, a critic must have wide and deep knowledge of this particular art field as well as related fields. Among critics such knowledge is usally called "connoisseurship" (,знаточество“), which is based on extensive reading and general erudition („наслушанность”, „начитанность”, „насмотренность“). In additon to that, there are a certain number of moral qualities required: professional honesty, sense of proportion, tactfulness, responsibility to the artist whose work is being analyzed. Alexander Pushkin wrote the following about this part of art criticism: "Criticism is a science which is aimed at discovering merits and shortcomings of works of art and literature. It is based on perfect knowledge of rules that an artist or a writer are guided by, careful study of models and intense observation of conscpicuous modern phenomina" [4, P. 159].

It is worth mentioning that the temporal factor also has a great impact on art criticism. In historical perspective a work of art becomes vulnerable to the arbitrariness of any director who understands it in his or her own way and whose vision and personality can distort the original meaning of a work of art. The reason for that is the estrangement of an artwork from its creator which develops over time and builds its own life, that is why sometimes the judgements of younger generation differ from those of contemporaries. These facts emphasize the intellectual richness of art criticism. Hence, the more educated a critic is, the more respect and trust he gains, the more value for the development of an artist's mastery his or her judgements have.

Nevertheless, nowadays there is a huge amount of artistic information of different quality accompanied by the increasing number of periodicals focusing on the modern arts. Very often the authors of such critiques are not professional arts critics but journalists who are completely unaware of methods of artistic analytics. It was an acute issue even in the XIX century, though that period was the most productive for literature. Alexander Pushkin touched this problem in his "Eugen Onegin" by putting there the following words:

“...The first chapter I've finished and set to rest. 
I have looked at the lot of it through and through

And in it there are many contradictions,

But to put them right is not my aim,

For censorship must have work to do,

And for the journalists for their devouring

The fruits of my labour I will consign.

Go then, little book, to the banks of the Neva,

My new born babe, my own creation,

And earn there for me renown's main gift:

Intemperate criticism and short shrift!..." [Available at: http://www. pushkins-poems.com/Yev019.htm (accessed 25 March 2015)].

The analysis of works of art is a specific field of cognition and description of a particular artistic phenomenon. In contrast to journalistic essays, professional reviews reveal the individuality of the critic's mind, his or her peculiar ways of describing an artwork, his or her understanding of an artist's emotional state involved in the process of creation, ulterior motives for an artist's work, knowledge of objective, historical conditions of an artist's life etc. Glaring examples of competent criticism are to be found in works by many researchers engaged in different art forms such as the musicologists Boris Astafyev and Gerold Gruber, the literary historian and linguist Viktor Zhirmunsky, the arts critic Dmitri Sarabyanov and many others.

\section{PURPOSES OF ART CRITICISM}

Works by proficiant arts critics become with the passage of time sources of intellectual and artistic information for the next generations of art researchers and art admirers. Sometimes young researchers are so inspired by works of great masters that they adopt their theories and methods and try to apply them to other times and countries. For example, that was the case with "Die Entwicklungsgeschichte der Stile in der bildenden Kunst" 1 by Ernst Cohn-Wiener which was published in this country in the period 1916-1940. Cohn-Wiener's main aim was to find out how one style develops into another from epoch to epoch. He tried to discover the patterns of this development linking it to the material and economic conditions of a particular time period.

At the same time, an artist never creates his or her work for the art history elite. The artist's intention is to express him- or herself, to share his or her vision with the audience. Each artist hopes to create such a work of art that will be accepted by as many people as possible. This is the way for him to receive recognition, fame, respect, and even admiration. So it comes that occasionally art criticism has nothing to do with it. Works by the poet and singersongwriter Vladimir Vysotsky, which are so familiar to this generation of the Russians, only prove the case. This also holds true for works by Vladimir Mayakovsky and
Alexander Puskin, who, each in his time, were able to win wide public recognition.

So far there has been little investigation of social functions that are performed by art criticism. The paradox about theory of history as a special field of scientific research is that the borders between art history and art criticism are not quite firmly drawn. So it happens that works of these two research fields frequently get mixed up. Eventually, as the study by Svetlana Gracheva shows, all fields of research mentioned above can be separated from each other only with difficulty [2].

So, what are the purposes which arts critics pursue in their everyday praxis?

\section{A. Censorship}

The aim of critical art analysis may be the exercise of censorship caused by the intention to restrict some ideas, methods, information or prevent their further spread. Such analysis is supposed to stop the spread of works of unsufficient quality, i. e. works that do not meet the current artistic, ideological, and ethical standards. Due to this fact such works may be considered as undesirable at the moment or even socially harmful. From the very beginning religious institutions were in charge of exercising censorship in the arts, then it became the responsibility of different state establishments. For instance, the French Academy in XVII century carried out these functions and censored writers' and playwrights' works. It decided if this or that artwork satisfied the standards of classicism and answered the state's purpose of strengthening the monarchy. The members of the Academy also sealed the fates of plays staged at the Comédie-Française. In particular, the play "Le Cid" by Pierre Corneille (1638) was banned as unworthy of being staged.

The history of different art forms, since the Middle Ages, is rich in examples of the strict control over printed materials, theatre performances including fixed and travelling ones. It was necessary to apply for special permissions not only to religious institutions but also to secular censors who among other duties should give critiques of new publications and art events of all kind.

The existence of censorship is closely connected with the acceptance of the state's right to restrict any information which is considered as harmful or undesirable in some respects. In mankind's history there has never been a society without censorship. From this point of view, art censorship does not differ from any other kind of censorship. However, art censors pay attention not only to the political and moral criteria but also attach great importance to the aesthetic level of a work, which could be referred to as "judgement of taste“ („суждение вкуса“). Works of low aesthetic quality, provided that they are made public, may instil into the consciousness of its consumers and producers as well as the illusion of official encouragement of artistic carelessness. It is a dangerous path which leads to aestheticdeterioration and the gradual decline of the arts. 


\section{B. Self-actualization}

Another purpose of art criticism can be the selfactualization of a critic. Being engaged in art analytics satisfies his or her need of personal artistic development and gives him the feeling of belonging to art creators' world. This group of critics are guided by ulterior motivation of self-assertion which, however, is not quite obvious. The public nature of criticism brings about publicity not only for an artist or an artists' group as well as their works but also for the critic himself. The critic and the artist, no matter what art form is considered, build a peculiar closed professional union with a unique atmosphere of mutual interest, competition and, still, reciprocal suspicion. The reason for that is, on the one hand, an artist's hope for the objective assessment of his or her work and, on the other hand, doubts about its objectiveness and fear of a negative critique.

\section{Mystification}

Art censorship can also be responsible for the mystification of the arts. Mystification is the deliberate or accidental delusion of the recipient regarding the value of an artwork. The mystification of the arts can be realized in form of a write-up (or regular reviews) dedicated to a poor work of art or in form of a distinctly negative review of an original artwork. It is worth mentioning that motives that induce people of different occupations to apply this method are numerous: envy of others' genius, lack of education, rejection of new ideas, expectation of praise in return or execution of a higher authority's order. A striking example of artistic mystification is the painting "The Black Square" by Kazimir Malevich. According to the painter's biography, after the first version of this painting had been finished, Malevich had nagging doubts about the appropriateness of showing his work to the public as a complete work of art, not as an artistic experiment. It can be explained by the fact that the presentation of an artwork to the public generally marks the end of the artist's work on it and launches the process of estrangement of this work from the author. Thus, the promotion of an unconvincing, unfinished from the professional standpoint, artwork may be viewed upon as a mystifying element of art criticism. For example, painting masterpieces are sometimes used by advertising for soap or other consumer goods.

\section{Aesthetic and educational purposes}

The aims of aesthetic cultivation and education of the audience are closely related to each other. Art criticism is supposed to cultivate aesthetic tastes, to extend artistic horizons, to assist the audience in comprehending the peculiarities of an artist's work. It is not rare that people get acquainted with art masterpieces not in the original but through successful, from the literary point of view, reviews of them. Good critiques provide the reader with a quite sufficient impression of the historical circumstances in which a work of art was originally produced, people who served as prototypes of a work's characters, underlying motives for an artist's work and its style characteristics. Studies of this kind often turn out to be extremely informative. At the same time, the educational function of a critique can be performed in form of prediction. Vissarion Belinsky once commented on that issue: "When a newborn genius gives life to a new art field and leaves the old ruling critics behind, which is a death blow to them, he inevitably makes the space for the new arts by destroying the old ones" $[1,287]$.

Art criticism also fulfils the educational function towards an artist revealing the weak points of his or her work. Considering the professional ethics, the form in which a critical judgement is expressed is the most delicate issue, especially when there is a danger of repressions in a society. The famous Soviet satirical writer Yevgeny Petrov, recalling the times of RAPP (The Russian Association of Proletarian Writers in the 1930s), remarked: "Now it could make one laugh to learn that the name of Aleksey Tolstoy over the years was used with the addition "bourgeois-feudal writer", and Vladimir Mayakovsky was disparagingly called "a lumpen proletarian of literature, a hyperbolist". Mikhail Sholokhov was regarded as "fellow traveller suffering from morbid psychologism and uncapable of recognizing the real value of production achievements in Cossacks' life"... The literary fate of Sergei Sergeyev-Tsensky is very conspicuous in this respect. He was depicted as a hanged-man in the magazine "Na Literaturnom Postu" with the mocking inscription "a living dead". Small critics played around with this insulting reference encouraged by the dreadful label given to Sergeyev-Tsensky by RAPP itself. Taking that into account, the will-power of Sergeyev-Tsensky, his writer's discipline and industry appear even more amazing" $[3, \mathrm{P}$. 471-472].

\section{E. Evaluation}

Art critical studies voluntarily or not do their bit in ranking works of art according to their value, that is to say, according to the contribution to the world culture they are believed to have made. This ranking results with the passage of time in a "focality effect” (эффект „очаговости“), i. e. division of artworks into groups of first-rate, second-rate or third-rate value. The focality effect means that some artists and their works including the whole art movements receive more attention than others. The reasons for that may be different: on the one side, talent, artistic fertility or fame; on the other side, fashion names, large-scale studies, the reference index (articles, textbooks, monographs, dissertations, graduation papers, course projects etc.). In the long run, these materials form a reliable base that can be used in current studies. For instance, the modern praxis of musical performance in Russia (concerts, radio programmes, sound recording studios) pay greater regard to works by particular, usally the most prominent composers of the past centuries. Among them there are pieces by Baroque composers, certain pieces by composers of the First Viennese School, representatives of European music of the XIX century and Russian classical music namely Pyotr Tchaykovsky, Sergei Rachmaninoff, composers of the Mighty Handful. This is the way of how the dogmatic approach to maintaining the repertoire is formed and how the propagation of a great amount of world music, especially modern music, is hindered. As a result, the phenomenon of focality is to blame for stereotyping our consciousness 
which hampers the recipient's acquaintance with new art forms, endangers his or her general erudition and strengthens the conservatism of artistic tastes and preferences. Such conditions are extremely unbeneficial for the establishment of new art forms.

\section{IV.CONCLUSION}

Thus, art criticism pursues in its everyday praxis various socially significant aims.

\section{REFERENCES}

[1] V. G. Belinsky. Poln. sobr. soch. V 13 Tomakh. V. VI [Complete Works in 13 Volumes. Volume VI], Moscow, 1953-1959. (in Russian);

[2] S. M. Gracheva. Otechestvennaya Khudozhestvennaya Kritika XX Veka: voprosy teorii, istorii, obrazovaniya [Russian Art Criticism in the XX Century: Theory, History, Formation], St. Petersburgh, 2010 (in Russian);

[3] I.Ilf, Y.Petrov. Sobr. soch. V 5 Tomakh. V. 5 [Works in 5 Volumes. Volume 5], Moscow, 1961 (in Russian);

[4] A. S. Pushkin. Poln. sobr. soch. V 10 Tomakh. Izd. 3. Volume VII. [Works in 10 Volumes. 3 Edition. Volume VII], Moscow, 1963-1966 (in Russian);

[5] A. S. Pushkin. Poln. sobr. soch. V 6 Tomakh. T. 3 [Works in 6 Volumes. Volume 3], Moscow - Leningrad, 1937 (in Russian). 